Науковий вісник НлТУ України Scientific Bulletin of UNFU http://nv.nltu.edu.ua

https://doi.org/10.15421/40290725

Article received 27.08.2019 p.

Article accepted 26.09.2019 p.

УДК 614.8:621.56

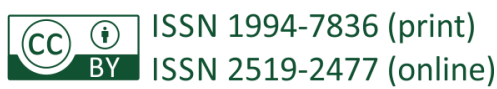

$@ \bowtie$ Correspondence author

O. F. Babadzhanova

olha.bab.52@ukr.net

О. Ф. Бабаджсанова, Д. П. Войтович

Львівський державний університет безпеки життєдіяльності, м. Львів, Україна

\title{
ВИКОРИСТАННЯ МЕТОДУ ҒТА ДЛЯ АНАЛІЗУ НЕБЕЗПЕКИ АМІАЧНИХ ТРУБОПРОВОДІВ
}

\begin{abstract}
Розглянуто можливість використання одного з методів імовірнісного аналізу безпеки - аналіз "дерева відмов" (FTA) для дослідження небезпеки аміачних трубопроводів. "Дерево відмов" є графічним представленням причинних взаємозв'язків для відшукання можливих причин виникнення аварій. В аміачних холодильних установках як холодоагент використовують хімічно небезпечну речовину - аміак, який циркулює по системі трубопроводів у газовій і рідкій фазах. Виявлено основні чинників небезпеки експлуатації трубопроводів аміачної холодильної установки. Побудовано "дерево відмов" для трубопроводів з аміаком. Оцінено вплив окремих відмов у роботі трубопроводів на небезпеку виникнення аварійної ситуації. Розроблено ймовірний сценарій розвитку аварії в разі пошкодження трубопроводів з рідким та газоподібним аміаком. Встановлено можливість застосування методу FTA для прогнозування аварійних ситуацій на аміачних трубопроводах, які впливають на техногенну небезпеку аміачної холодильної установки.
\end{abstract}

Ключові слова: потенційно небезпечний об'єкт; трубопровід; аміак; аварія; "дерево відмов"; небезпека.

Вступ. Запобігання надзвичайним ситуаціям (аваріям) на потенційно небезпечних об'єктах є однією 3 найактуальніших проблем сучасного виробництва. Ефективним засобом вирішення проблеми зниження техногенної небезпеки є спеціалізовані системи прогнозу і мінімізації ризику. Теоретичною основою оцінки небезпеки є імовірнісний аналіз безпеки (ІАБ), який набув досконалого розвитку стосовно об'єктів атомної енергетики. Передові технології ІАБ поширює Міжнародне агентство 3 атомної енергетики в усі зацікавлені країни безкоштовно. Найбільш відомим $є$ пакет прогpaм "Integrated Reliability and Risk Analysis" (IRRAS).

Стосовно проблем безпеки, методи IАБ набули найширшого застосування в атомній енергетиці (Begun et al., 2000), а також на виробничих об'єктах, де $є$ потенційна можливість викидів токсичних речовин, вибухів небезпечних речовин, вибухів резервуарів високого тиску і трубопроводів, розлиття горючих речовин (Коvalevich, 2006; Serebrovsky, 2007; Lysyuk, 2005; Serebrovsky, 2014). Основними моделями, які використовують в ІАБ, є логіко-імовірнісні моделі "дерево відмов" і "дерево подій". Ці моделі можна використовувати і для оцінки пожежної безпеки об'єктів (Serebrovsky, 2015).

Аналіз "дерева відмов" (Fault-tree analysis - FTA) спочатку було розроблено в Америці. У 1961 р., вивчаючи оцінку безпеки пускової системи управління ракетою, Уотсон з інституту Baer у США вперше запропонував цей метод. Пізніше Мінс у лабораторії Bell разом 3 іншими експертами покращили цей метод, щоб вирі- шити проблему прогнозування випадкових аварій в ракетах. Комісія з атомної енергетики США оцінила небезпеку комерційних атомних електростанцій і випустила звіт Расмуссена, який привернув увагу всього світу в 1974 р. Китайці почали вивчати і використовувати методи FTA в 1987 р. у деяких галузях, таких як: авіація, хімічна та атомна промисловість, металургія і техніка (Junfeng Wang, 2018).

FTA - це метод дедуктивного мислення, де логічний зв'язок між потенційними аваріями і відповідними причинами можна представити деревоподібними діаграмами. FTA став одним із найпопулярніших методів у системному аналізі. Він може описати динамічний процес виникнення і розвитку аварій, з'ясувати прямі й непрямі причини і поєднання цих причин. Аналізуючи FTA якісно і кількісно, можна знайти основні причини, забезпечити надійну основу для визначення заходів безпеки, для прогнозування і запобігання аварій. "Дерево відмов" є спрямованим логічним деревом, яке описує виникнення аварій від результату до причини. Технологія аналізу дерева знаходиться до категорії теорії графів інженерії систем (Marshall, 1989; Khenli \& Kumamoto, 1984).

Найпоширенішим методом оцінювання небезпеки й аварійності виробництв є розроблення формалізованих моделей розвитку подій - використання методу "дерева відмов". Методику застосування цього методу оцінювання ризику опрацьовано в сучасній науково-технічній літературі (Averin \& Moskalets, 2008; Taraduda \&

\section{Інформація про авторів:}

Бабаджанова Ольга Федорівна, канд. техн. наук, доцент, кафедра цивільного захисту та комп'ютерного моделювання екогеофізичних процесів. Email: olha.bab.52@ukr.net

Войтович Дмитро Петрович, канд. техн. наук, кафедра цивільного захисту та комп'ютерного моделювання екогеофізичних процесів. Email: voytovych.dmt@gmail.com; https://orcid.org/0000-0002-2280-5585

Цитування за ДСТУ: Бабаджанова О. Ф., Войтович Д. П. Використання методу FTA для аналізу небезпеки аміачних трубопроводів. Науковий вісник НЛтУ України. 2019, т. 29, № 7. С. 124-128.

Citation APA: Babadzhanova, O. F., \& Voytovych, D. P. (2019). Using the Fta Method for Hazard Analysis of Ammonia Pipelines. Scientific Bulletin of UNFU, 29(7), 124-128. https://doi.org/10.15421/40290725 
Shevchenko, 2009; Taraduda et al., 2010).

Метод "дерева відмов" набув широкого застосування у світі для аналізу ризику аварій на об'єктах підвищеної небезпеки. FTA застосовують як для попереднього аналізу рівня безпеки під час розроблення рекомендацій для зниження рівня ризику, так і для розслідування причин аварій на небезпечних технологічних об'єктах. В Україні та Росії метод FTА застосовують під час розроблення декларації безпеки об'єктів підвищеної небезпеки.

Автори (Babeshko \& Kharchenko, 2009) проаналізували можливості спільного використання сучасних методів аналізу відмов систем FTA, FMEA, HAZOP, RBD. У статті (Sharov \& Makarov, 2011) розглянуто комбінацію двох методів аналізу надійності FTA-FMEA для розрахунку (прогнозування) ризику авіаційної події.

Головна перевага FTA (порівняно з іншими методами) полягає в тому, що аналіз обмежується виявленням тільки тих елементів системи і подій, які призводять до конкретної відмови системи або аварії.

Для вироблення штучного холоду на підприємствах харчової та переробної галузі використовуються аміачні холодильні установки (АХУ). Їх призначено для забезпечення холодом технологічного обладнання виробничих цехів і підтримання необхідного температурного режиму на складах зберігання продукції. Як холодоагент використовують хімічно небезпечну речовину аміак, який циркулює по системі трубопроводів у газовій і рідкій фазах. Аміачні холодильні установки $є$ об'єктами підвищеної небезпеки, аварії на яких через токсичність аміаку, а також через розташування підприємств у населених пунктах можуть призвести до важких наслідків.

Проаналізовані авторами (Makhovs'kyy \& Kryukovs'ka, 2014) аварії та аварійні ситуації, пов'язані 3 експлуатацією аміачних холодильних установок на території України за десять років, можна класифікувати за такими категоріями: недотримання правил експлуатації - $76 \%$; недосконалість систем охолодження $17 \%$; дефект монтажу - $5 \%$; заводський брак обладнання $-2 \%$.

Широкомасштабне застосування аміаку і недосконалість основного й допоміжного технологічного обладнання призводять до високого рівня аварійності на підприємствах, які використовують аміак. У поєднанні 3 низьким рівнем професійної підготовки виробничого персоналу щодо дій в аварійних ситуаціях це може призвести до ланцюгового характеру розвитку аварії і неконтрольованого зростання iï масштабів (Belova \& Kaluzhskiy, 2018). Тому аналіз небезпеки технологічного обладнання, в якому обертається аміак, має актуальне значення для запобігання виникненню аварій.

Матеріал і методи дослідження. FTA знаходиться в основі логіко-ймовірнісної моделі причинно-наслідкових зв'язків відмов системи з відмовами ії елементів та іншими подіями (впливами). Під час аналізу виникнення відмови "дерево відмов" складається з послідовностей і комбінацій порушень і несправностей, і в такий спосіб воно $є$ багаторівневою графологічною структурою причинних взаємозв'язків, отриманих внаслідок простеження небезпечних ситуацій у зворотному порядку для того, щоб відшукати можливі причини їх виникнення (рис. 1).

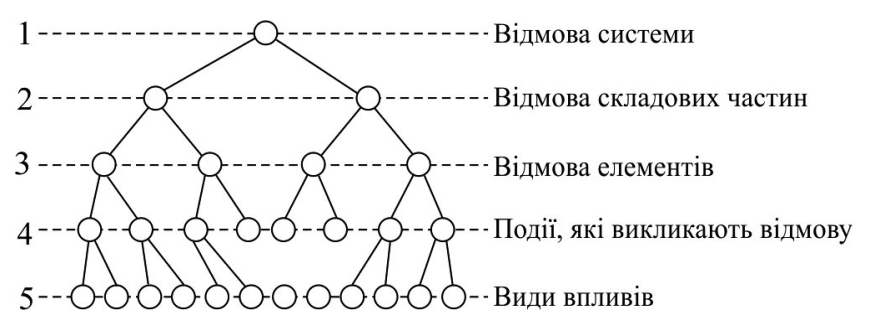

Рис. 1. Умовна схема побудови "дерева відмов"

Створення "дерева відмов" починається з визначення кінцевої події. Ця кінцева подія буде розташовуватись на верхівці "дерева", а всі наступні події, які ведуть до головної, будуть розташовуватись як гілки на дереві. Розташовуючи кожний чинник у відповідному місці "дерева", є можливість визначити, де відбулись будь-які пошкодження у системі, який зв'язок існує між подіями і яка взаємодія відбулась (чи не відбулась, але може відбутись).

Побудову "дерева відмов" виконували з використанням стандартизованого графічного представлення подій і логічних символів зв'язку між подіями.

Для того, щоб перейти від одного рівня "дерева" до наступного, потрібно постійно ставити фундаментальне запитання: "Що могло б призвести до здійснення цієї події?" Як тільки причинні події ідентифіковані, вони розміщуються у відповідній позиції на "дереві відмов".

Щоб відшукати i наочно уявити причинний взаємозв'язок за допомогою "дерева відмов", необхідні елементарні блоки, які підрозділяють і зв'язують події. $€$ два типи блоків: логічні символи (знаки) і символи подій.

Під час побудови "дерева відмов" використовували спеціальні символи, які забезпечують нас ілюстрованим зображенням події (рис. 2). Спеціальна форма символів дає наочність і значно полегшує побудову "дерева відмов".

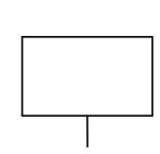

a)

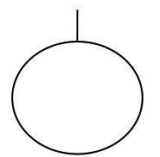

б)

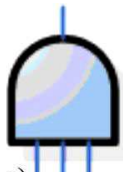

6)

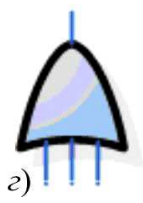

Рис. 2. Умовні позначення: а) найпоширеніший тип подій (головна або сприятлива подія); б) основна (вихідна) подія; "I" вихідна подія відбувається, якщо всі вхідні події трапляються одночасно; "АБО" - вихідна подія відбувається, якщо трапляється будь-яка з вхідних подій

Прямокутний базисний елемент - це головна подія, тобто така небажана подія, яка можлива під дією чинника, або сприятлива - така, що веде до появи головної події.

Базисний елемент круглої форми - це відмова устаткування, людська помилка (похибка) чи несприятлива умова. Коло означає, що подія відмови не потребує подальшої розробки.

Базисні події поєднуються між собою логічними елементами, які інформують про результат події.

Логічний символ може мати один чи кілька входів, але тільки один вихід чи вихідну подію.

Для попереднього аналізу небезпек використовують як прямий підхід, так і зворотний. Для виконання аналізу в прямому порядку приймають певні послідовності подій і складають відповідні цим наслідкам сценарії, які закінчуються небезпечними станами системи. Зворотний підхід, тобто аналіз за допомогою "дерева від- 
мов", використовують для визначення причинних зв'язків, які ведуть до цього небезпечного стану системи.

Результати дослідження. Прийняття необхідних та ефективних управлінських рішень, спрямованих на розробку заходів щодо запобігання аварійним ситуаціям, зумовлюється результатами аналізу небезпеки виникнення ймовірних аварій в небезпечних місцях технологічних систем об'єктів. Розглянемо деякі особливості моделювання аварійних ситуацій на прикладі трубопроводів транспортування аміаку в межах аміачної холодильної установки.

Потенційна небезпека аміачної холодильної установки полягає у порушенні герметичності обладнання і трубопроводів, які містять аміак. Найбільшою небезпекою 3 цього погляду є руйнування трубопроводів з рідким аміаком; руйнування напірних трубопроводів компресорів; порушення герметичності лінійних та циркуляційних ресиверів, запірної арматури, батарей холодильних камер.

Технологічно і територіально трубопроводи аміачної холодильної установки поділено на:

- трубопровід для зливу рідкого аміаку з автоцистерни (розташований на відкритому майданчику);

- трубопроводи рідкого аміаку з лінійних ресиверів у компресорне відділення (розташовані на естакаді на відкритому майданчику);

- трубопроводи обв'язки компресорів (розташовані в приміщенні);

- трубопроводи обв'язки конденсації та збереження аміаку (розташовані на відкритому майданчику).

Прогнозовано аварійні ситуації і аварії на трубопроводах аміаку.

Витоки і викиди аміаку можуть відбуватися тільки у випадку порушення герметичності чи руйнування трубопроводів, а саме:

• порушення герметичності фланцевих з'єднань трубопроводів і трубопровідної арматури;

- порушення герметичності ущільнень трубопровідної арматури;

- порушення цілісності зварних швів;

• порушення цілісності тіла труби чи трубопровідної арматури.

У межах обв'язки компресорів, руйнування трубопроводів можливе внаслідок зовнішнього механічного впливу під час виконання ремонтних робіт, виходу параметрів за критичні значення, помилок обслуговуючого персоналу.

Найбільш ймовірним і поширення варіантом порушення герметичності фланцевих з'єднань $є$ відсутність герметичності між поверхнями прокладки і фланця. Такі порушення герметичності не становлять небезпеки на відкритому майданчику, тому що пара аміаку легша за повітря і під час незначних витоків не здатна збиратися і створювати вибухонебезпечні газоповітряні суміші.

Значну небезпеку становить так зване "видавлювання" прокладки, тобто витік аміаку утвориться внаслідок порушення цілісності прокладки і викиду сегмента прокладки з фланцевого з'єднання. Така ситуація можлива для фланцевих з'єднань трубопроводів і арматури 3 дефектною прокладкою.

Порушення цілісності зварних швів може бути незначним (крапковим чи у вигляді невеликої тріщини), так звані "свищі" i, навпаки, з повним чи частковим руйнуванням (розтріскуванням) зварного шва.
Руйнування зварних швів зумовлені наявністю внутрішніх напружень у неправильно звареному шві та зазвичай стаються під час зміни температури трубопроводів.

Порушення цілісності тіла труби чи трубопровідної арматури можливе внаслідок корозійного або втомного зношування металу, а також у випадку неякісного виготовлення.

Руйнування трубопроводу можливе внаслідок зовнішнього механічного впливу під час виконання ремонтних робіт, руйнування опорних конструкцій, дії зовнішніх природних чинників.

Причинами витоків рідкого аміаку внаслідок незначних порушень герметичності трубопроводу можуть бути:

- корозія металу трубопроводів і арматури;

- нещільність зварних швів, фланцевих з'єднань і ущільнень трубопровідної арматури внаслідок підвищення тиску в системі, неякісно виконаного ремонту і ревізії стану трубопроводів і арматури.

Причинами залпових (масових) викидів рідкого чи газоподібного аміаку внаслідок значних порушень герметичності трубопроводів можуть бути:

- підвищення тиску в системі;

- значні механічні ушкодження та руйнування трубопроводів і арматури від зовнішніх впливів (аварії на сусідніх виробництвах, аварії транспортного характеру, ушкодження під час виконання ремонтних чи вантажно-розвантажувальних робіт у межах установки чи в безпосередній близькості від неї, природні чинники);

- інтенсивна корозія трубопроводів і арматури через зовнішній вплив агресивних речовин.

У випадку значного порушення герметичності чи руйнування трубопроводу рідкого аміаку між конденсаторами і лінійним ресивером викид аміаку із системи може бути максимальним.

На підставі аналізу аварійних ситуацій на трубопроводах розроблено варіант графа "дерева відмов" для трубопроводів аміачної холодильної установки. Ініціюючою подією в аварійній послідовності $є$ викид (розлив) аміаку. Граф (рис. 3) є логіко-імовірнісною моделлю причинно-наслідкових зв'язків аварійності трубопроводу з відмовами його елементів та іншими впливами, які призводять до викиду технологічно небезпечного середовища (аміаку).

Ліва гілка в цій моделі враховує утворення незначного протікання на трубопроводі внаслідок втоми чи корозії металу, розгерметизації зварних швів або запірних пристроїв у разі неякісного контролю стану обладнання (через можливі помилки персоналу під час ревізування стану трубопроводів та запірної арматури). Права гілка характеризує причини значних порушень герметичності трубопроводів (руйнування), до яких можуть призвести вихід параметрів процесу за критичні значення внаслідок відмови вимірювальної апаратури та можливих помилок обслуговуючого персоналу, дія зовнішніх чинників. Тобто викид аміаку з трубопроводу може реалізуватись тільки в разі порушення його цілісності.

Під час розгляду причин відхилень враховували відмови контролюючого устаткування, арматури, несправності, а також можливі технологічні причини, зумовлені порушенням режимів роботи трубопроводів. 


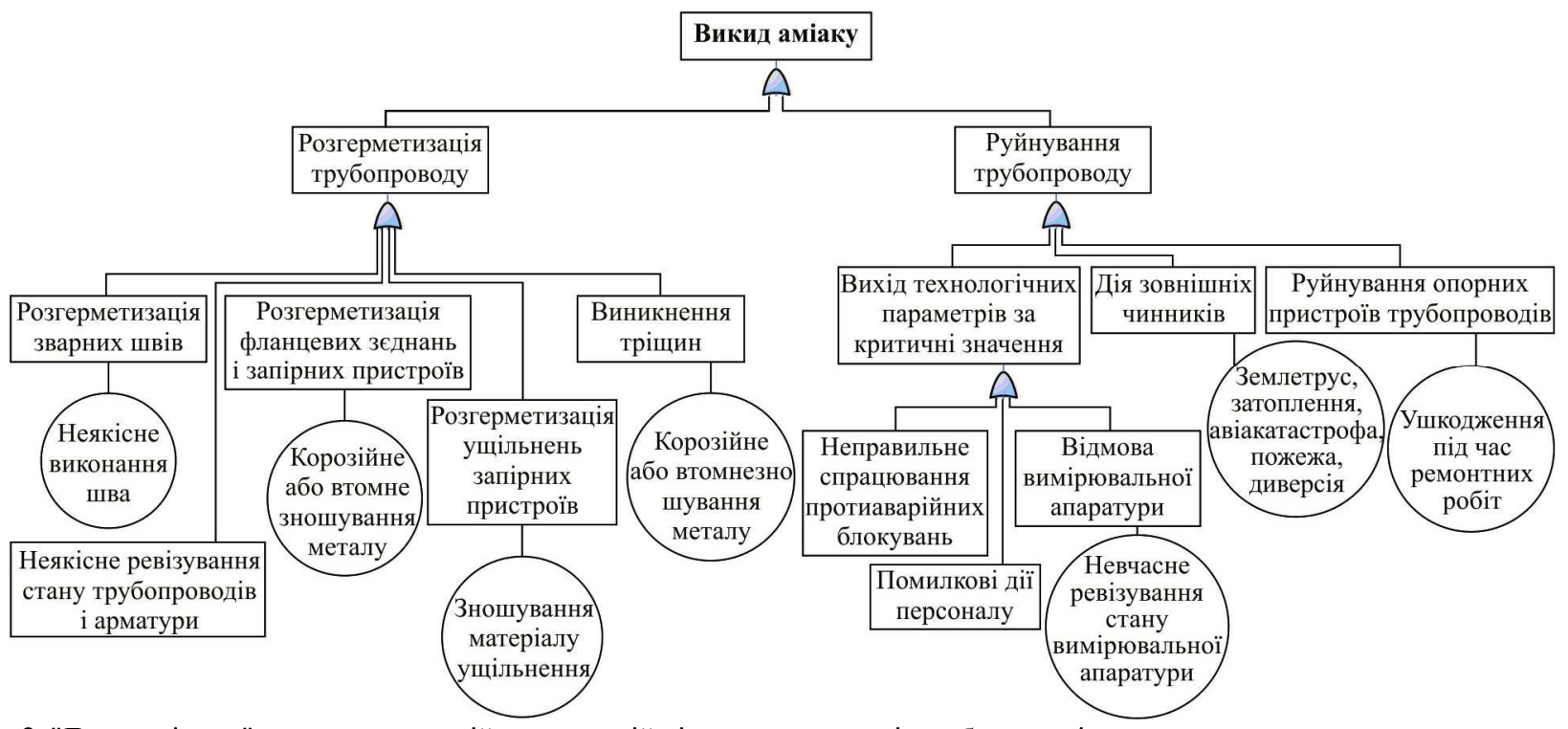

Рис. 3. "Дерево відмов" виникнення аварійних ситуацій під час експлуатації трубопроводів

Аналіз перерізів "дерева відмов" свідчить про те, що найнебезпечнішим для реалізації аварійної ситуації може стати таке сполучення подій:

- неякісне ревізування стану трубопроводу та запірної арматури;

• розгерметизація трубопроводів з причини втоми чи корозії металу;

- вихід технологічних параметрів за критичні межі.
Для оцінки техногенної небезпеки необхідно встановити причинні зв'язки між впливом потенційно небезпечного чинника і розвитком несприятливих наслідків. Залежно від агрегатного стану аміаку в трубопроводах і характеру їх руйнування, розвиток аварійної ситуації може відбуватися за подальшим нижче сценарієм (рис. 4).

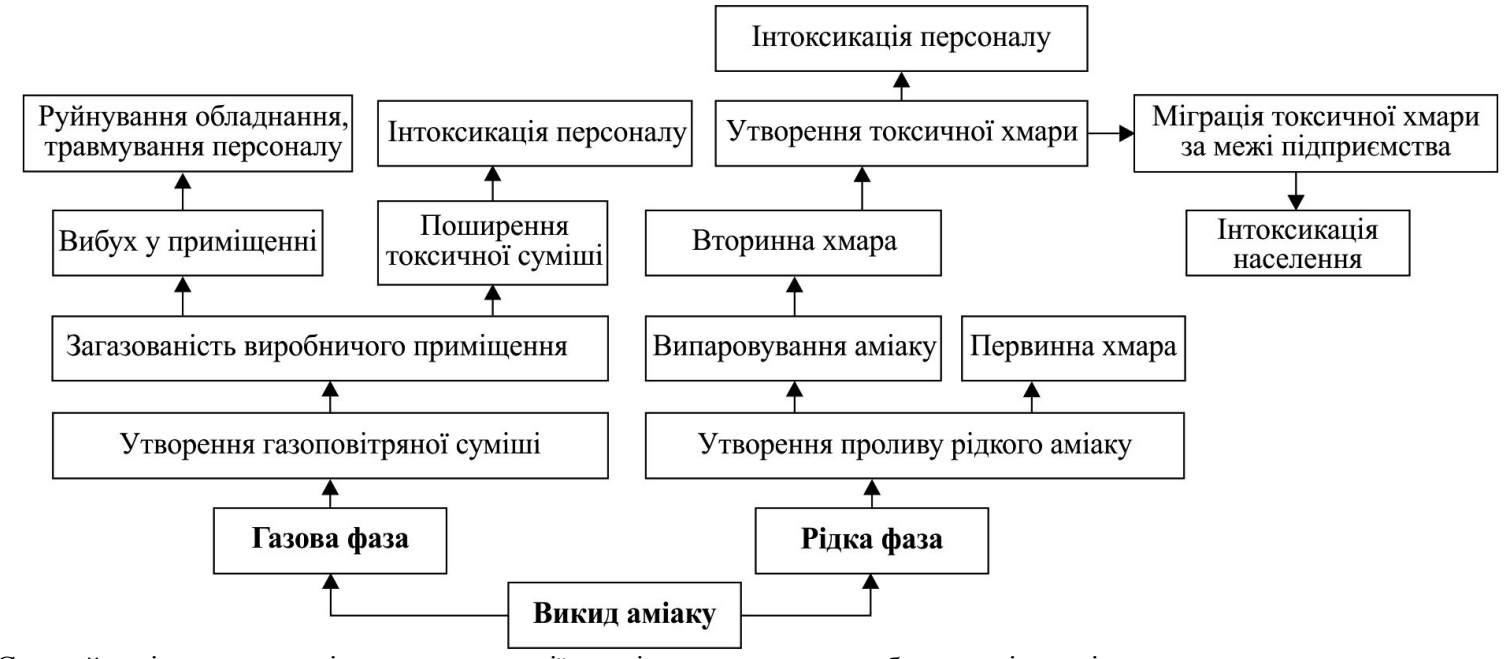

Рис. 4. Схема ймовірного сценарію розвитку аварії в разі пошкодження трубопроводів з аміаком

Усе обладнання та комунікації АХУ перебувають під тиском. Порушення норм технологічного режиму щодо тиску, температури, рівня тощо, недотримання умов герметизації трубопроводів та арматури можуть призвести до перевищення концентрації аміаку в повітрі робочої зони, вибуху, інтоксикації людей.

Вихід аміаку в разі руйнування трубопроводу може відбуватися як миттєво, так і протягом деякого часу. Під час аварії, яка розвивається в разі розгерметизації трубопроводу, аміак надходить в навколишнє середовище через нещільності чи отвори протягом деякого часу. Найнебезпечнішим випадком є розлив (викид з трубопроводу) рідкого аміаку, який миттєво переходить у газоподібний стан $з$ утворенням токсичної хмари.

Висновки. У випадку порушення герметичності трубопроводу відбудеться витік чи викид аміаку, які можуть призвести до утворення токсичної хмари в приміщенні чи на відкритому майданчику, інтоксикації персоналу, міграції токсичної хмари в межах підприємства чи за його межі.

Обсяг витоку рідини зазнаходиться від розмірів ушкодження, яке утворилося внаслідок порушення герметичності труби, тривалості виходу аміаку з ушкодження (нещільності) і надлишкового тиску в ушкодженій ділянці трубопроводу.

Небезпека викидів аміаку в атмосферу здебільшого пов'язана 3 низькою якістю ремонту і ненадійною герметизацією трубопроводів та устаткування, що за великих динамічних знакозмінних навантажень призводить до руйнування, особливо в місцях роз'ємних з'єднань.

За допомогою досліджень взаємовпливів відмов основних елементів трубопроводу визначили можливі сценарії розвитку аварійної ситуації та за допомогою побудови "дерева відмов" навели причини відмов елементів трубопроводу. 
Найбільш ймовірні аварії можливі в разі часткового чи повного руйнування промислових аміачних трубопроводів. Використання методу FTA дає змогу застосувати "дерево відмов" для виявлення та якісного опису причин виникнення аварійних ситуацій на трубопроводах та спрогнозувати наслідки розвитку аварій.

\section{Перелік використаних джерел}

Averin, G. V., \& Moskalets, V. M. (2008). Analiz opasnostey ammiachnykh kompressornykh ustanovok metodom postroyeniya "dereva otkazov". Ecological safety scientific journal, 3-4, 9-16. [In Russian].

Babeshko, E. V., \& Kharchenko, V. S. (2009). Possibilities of combined usage of failure analysis methods for safety-critical systems. Radioelectronic and computer systems, 6(40), 60-64. [In Russian].

Begun, V. V. (Ed.), Горбунов, О. В., Каденко, И. Н., at al. (2000). Veroyatnostnyy analiz bezopasnosti atomnykh stantsiy (VAB). Kiev: NTUU "KPI", 568 p. [In Russian].

Belova, T. I., \& Kulazhskiy, E. V. (2018). Analysis of potentially dangerous technological processes and sources of increased danger when using ammonia in food industry enterprises. Nauchno-prakticheskiy elektronnyy zhurnal Alleya Nauki, 2(18). Retrieved from: https://alley-science.ru/domains data/files/February18/. [In Russian].

Khenli, E. Dzh., \& Kumamoto, Kh. (1984). Nadezhnost tekhnicheskikh sistem i otsenka riska. (Trans. from English). Moscow: Mashinostroyeniye, 528 p. [In Russian].

Kovalevich, O. M. (2006). Risk in the technogenic sphere. Moscow: MEI, 152 p. [In Russian].

Lysiuk, S. D. (2005). Rozrakhunok ymovirnosti otruiennia amiakom z vykorystanniam kodu IRRAS. Problemy okhorony pratsi v Ukraini, 9, 46-55. Kiev: ННДІОП. [In Ukrainian].

Makhovskyi, V. O., \& Kriukovska, O. A. (2014). Analiz avariinykh sytuatsii i avarii amiachno-kholodylnykh ustanovok na pidpryiemstvakh kharchovoi ta pererobnoi promyslovosti. (Ser. Technical Sciences). Collection of scholarly papers of Dniprovsk State Technical University, 1(24), 291-297. [In Ukrainian].

Marshall, V. C. (1989). Osnovnye opasnosti khimicheskikh proizvodstv. (Trans. from English). Moscow: Mir, 672 p. [In Russian].

Serebrovskiy, A. N. (2007). Metody otsenki veroyatnostey otkazov v protsessakh prognozirovaniya tekhnogennykh chrezvychaynykh proisshestviy. Matematychni mashyny $i$ systemy, 2, 111-116. [In Russian].

Serebrovskiy, A. N., Eremenko, T. K., \& Pilipenko, Yu. G. (2015). Primeneniye modeley dereva sobytiy i dereva otkazov pri otsenkakh pozharnoy bezopasnosti zdaniy. Systemy pidtrymky pryiniattia rishen. Teoriia i praktyka. Xth scientific and practical conference, Kiev, June, 2015. (pp. 101-103). Retrieved from: http://conf.atsukr.org.ua/ conf/art collection.jsp?conf id=24. $\quad$ [In Russian].

Serebrovskiy, A. N., Oksanich, I. N., Eremenko, T. K., \& Pilipenko, Yu. G. (2015). Probabilistic safety assessment in assessment of object fire hazard degree. Scientific Bulletin UkrNDIPB, 1(31), 46-55. [In Russian].

Serebrovsky, O. M. (2014). Hazard Control Technology During Situation Monitoring At Potentially Hazardous Facilities. Journal of Scientific Research \& Reports, 3(18), 2382-2394.

Sharov, V. D., \& Makarov, V. P. (2011). The methodology of use of unified FTA-FMEA method for aviation accident risk assessment. Civil Aviation High TECHNOLOGIES, 174, 18-24. [In Russian].

Taraduda, D. V., \& Shevchenko, R. I. (2009). Formuvannia alhorytmu otsinky ryzyku vynyknennia avarii na potentsiino nebezpechnykh obiektakh, do skladu yakykh vkhodiat amiachni kholodylni ustanovky. Problems of Emergencies, 10, 161-170. Kharkiv: УЦЗУ. [In Ukrainian].

Taraduda, D. V., Shevchenko, R. I., \& Shcherbak, S. M. (2010). Determination indexes of danger basic elements of ammoniac refrigeration unit by the multicriterion method of estimation and management the risk origin of failures. Problems of Emergencies, 12, 155167. Kharkiv: УЦЗУ. [In Ukrainian].

Wang, J. (2018). In Safety Theory and Control Technology of HighSpeed Train Operation. Retrieved from: https://doi.org/10.1016/C2016-0-04352-8.

O. F. Babadzhanova, D. P. Voytovych

Lviv State University of Life Safety, Lviv, Ukraine

\section{USING THE FTA METHOD FOR HAZARD ANALYSIS OF AMMONIA PIPELINES}

The prevention of emergencies (accidents) at potentially hazardous objects is an urgent problem of modern production. The most common method of assessing the hazards and accidents of production is to develop formalized models of events - the use of the Fault Tree Analysis (FTA) method. Tree of failures is a directed logical tree that describes the occurrence of an accident from result to cause. Ammonia refrigeration units are used to produce artificial cold at food and processing enterprises. They are potentially hazardous objects, and accidents due to ammonia toxicity and the location of businesses in settlements can have serious consequences. Some features of emergency modelling are considered on the example of ammonia transportation pipelines within the ammonia refrigeration unit. The causes of pipeline damages that can lead to emergencies at ammonia pipelines are identified. Ammonia leaks and emissions can only occur if pipelines are broken or destroyed. Based on the analysis of emergencies on pipelines, the variant of the graph of tree of failures is developed for pipelines of ammonia refrigeration units. The initiating event in the emergency sequence is the emission (spillage) of ammonia. A probable scenario of accident development in the case of damage to pipelines with liquid and gaseous ammonia is developed. Leakage or emission of ammonia will occur if the pipeline leaked, which can lead to the formation of a toxic cloud indoors or outdoors, the intoxication of personnel, the migration of a toxic cloud within the enterprise or beyond. Through the research of the mutual effects of failures of the main elements of the pipeline we identified possible scenarios for the development of an emergency and using the construction of tree of failures shows the causes of failures of the elements of the pipeline. As a result, the FTA logic-probabilistic model can used to analyse the technogenic hazard of ammonia pipelines, enabling the prediction of accidents and emergencies.

Keywords: potentially hazardous objects; pipeline; ammonia; accident; tree of failures; hazard. 